\title{
An Examination of the Noken and Indigenous Cultural Identity: Voices of Papuan Women
}

\author{
Veronika Kanem ${ }^{1}$, Adele Norris ${ }^{1 *}$ \\ ${ }^{1}$ University of Waikato, Private Bag 3105, Hamilton, NEW ZEALAND
}

*Corresponding Author: adele.norris@waikato.ac.nz

Citation: Kanem, V. and Norris, A. (2018). An Examination of the Noken and Indigenous Cultural Identity: Voices of Papuan Women, Journal of Cultural Analysis and Social Change, 3(1), 01. https://doi.org/10.20897/jcasc/86189

Published: April 20, 2018

\begin{abstract}
Noken is an essential tool/bag/clothing in the lives of Indigenous people of West Papua, which is made from knitting thin strips of wood primarily from the Gnetum Gnemon tree. Raw materials required to make noken have become scarce due to massive deforestation. An analysis of the noken lends itself to a useful understanding of the link between economic development initiatives in the Merauke Regency of West Papua and shifting cultural identity among Indigenous Papuans. Drawing on the Women, Culture and Development (WCD) approach, this qualitative study examines interviews from Papuan women in order to understand how the noken resonates with Indigenous Papuans, and how perceptions of noken and their accessibility have changed. The findings reveal that a combination of factors contribute to dwindling noken supplies, which adversely impact Papuans' ability to produce and reproduce their culture. This paper argues that Papuan women possess an unwritten specialized knowledge that is of increased value in a shifting social context and holds new meaning in response to competing influences of non-Papuans.
\end{abstract}

Keywords: cultural identity, West Papua, indigenous women, Noken, resistant knowledge

\section{INTRODUCTION}

Since the 1960s, Indigenous Papuans have undergone a massive transition due to the loss of their native lands to intensive agriculture and other development schemes (Hadiprayitno, 2015; Stott, 2011). This transition resulted in very limited gains in the lives of Indigenous people of West Papua (Stott, 2011) and is underexplored in academic research. As reported by the Forest Peoples Programs (2013), economic development has both marginalized and alienated the Indigenous people through the lack of employment opportunities (Stott, 2011), scarcity of traditional foods (Wardis, 2014), and a diminishing presence in spaces once traditionally Indigenous (Free Peoples Program, 2013). In addition to providing their basic needs such as food, raw materials, water, and medicines, the forest represents their cultural identity (Free Peoples Program, 2013).

Using the Noken, an important cultural item/tool, this article examines the impact of economic development projects on Papuans' capacity to transmit longstanding cultural practices. We situate cultural practices as forms of knowledge that are unique to Papuan culture and communally known as knowledge (Berkes et al., 2000; IkojaOdongo, 2009; Smith 2012). Thus, it is a complex process that involves Papuans' intimate connection and experiences with the forest and the local environment. To discuss traditional knowledge and customs, we deploy the following definition of traditional ecological knowledge. 
Traditional Ecological Knowledge (TEK) represents:

a cumulative body of knowledge, practice, and belief, evolving by adaptive processes and handed down through generations by cultural transmission, about the relationship of living beings (including humans) with one another and with their environment. (Berkes et al. 2000, p. 1252).

Data from interviews with Papuan women provide insight into Papuan identity, voice, and marginalization. Insight into complex power dynamics associated with a transition into a market economy also shed light on aspects of coloniality. When discussing traditional cultural practices, the participants deployed four discursive themes: diminishing access to raw materials/forest, weakening social networks, shifting cultural values, and weakening transmission of cultural traditions/skills.

\section{West Papua: A Province of Indonesia}

West Papua is a province of Indonesia located east of Indonesia. It shares an eastern border with Papua New Guinea, and is surrounded by the Arafura Sea to the west, and the Pacific Ocean. A hidden paradise, West Papua is currently facing arduous changes that are largely unknown to most of the world. Indonesia's link to West Papua dates back to the 1800s. In 1826, Indonesian nationalists were able to successfully claim all sprawling territories of the Dutch East Indies for just one successor state (Banivanua-Mar, 2008; King, 2004; Lawson, 2016; Stott, 2011). Between the years 1949 and 1962, the remaining Dutch East Indies, including West Papua, formally became Indonesia (Lawson, 2016; Stott, 2011). Indonesia's presence in West Papua expanded rapidly during the 1960s. Justification for this expansion and eventual rule over West Papua was the claim to raise the living standards of the ethnically distinct 'primitive' Papuans (Stott 2011, p. 1). This process pushed native Papuans to develop a sense of a common Papuan identity in opposition to Indonesia's sovereignty over West Papua (Stott, 2011). For this reason, Indigenous peoples in this paper are exclusively referred to as Papuans. Thus, West Papua's complex history as a former Dutch colony and its status as a territory of Indonesia warrants a certain sensitivity when discussing concerns related to Papuans.

\section{Modernity, Loss of Native Lands, and Traditions}

Modernization in the Global South has been realized through various types of development programs and schemes (Ginting and Pye, 2013; King, 2004; Stott, 2011). Aggressive implementation of economic development programs facilitated the Javanisation (Javanese cultural domination) of West Papua-a process involving the economic and social transitions that accompanied this settlement and exploited the Indigenous occupants' use of customary systems for verifying land ownership (Banivanua-Mar, 2008; King, 2004). For example, customary practices for documenting land rights left Papuan's ancestral lands vulnerable to manipulation that ultimately led to massive losses of Indigenous land (Banivanua-Mar, 2008; Free Peoples Program, 2013). It has been long acknowledged that separating indigenous people from their land is a feature of colonization (Cooper, 2012; Mignolo, 2012; Smith, 2012). Smith (2012) states that this separation occurred in many forms: the forced division of land into individualize titles, seizure of land for "acts of rebellion" and through redefining land as "waste land" or "empty land" (p. 71). Similarly, Papuan state government was able to claim Indigenous lands to further industrial and agricultural development (Ginting and Pye, 2013; Free Peoples Program, 2013). This process classified millions of hectares of Indigenous land as empty land (Ginting and Pye, 2013). After which, multinational organizations laid claim to or simply grabbed massive Indigenous land areas to convert into industry (Forest Peoples Program 2013; Ginting and Pye, 2013; King, 2004). Under the pretext of "development," many natural forest ecosystems, essential to the survival of the Indigenous people, were destroyed by deforestation. Not only did this process dispossess Papuans of their native lands, it also ushered in a market economy.

Massive deforestation of native lands severely disrupted Papuans' way of life (Forest Peoples Program, 2013; Hadiprayitno, 2015). When the Indigenous people handed over their lands as part of participation in the economic development, a process described by some researchers as more of a "land grab" (see Ginting and Pye, 2013; Hadiprayitno, 2015), the Indigenous people were profoundly affected. Native lands were considered the wealth Papuans passed down to their children. The negative implications associated with this loss, are still largely unknown and unexamined from the perspective of the Indigenous people. Features of this process, however, are akin to historical forms of Western imperialism and colonization (King, 2004). Modernity, as described by Mignolo (2012), is synonymous with capitalism. "The idea of people not being able to get by without Europe's theoretical or culture achievements is one of the most definitive tenets of modernity" (Maldonado-Torres, 2004, p. 32). Accordingly, "coloniality is the underbelly or dark side of modernity" (Cooper, 2012, p. 66). Distinct from colonization, which implies something historical and structural, coloniality infers an ongoing process that is both fluid and dynamic. Moreover, coloniality is the modern model of power "that links together racial formation and knowledge production" (Maldonado-Torress 2004, p. 39 as cited in Cooper, 2012). 
As stated earlier, Papuans see themselves as racially and ethnically distinct from all other regions in Indonesia and identify more with other Melanesian populations, than with Asians (Lawson, 2016; Stott, 2011). Long before being absorbed by Indonesia, West Papua considered themselves part of the Pacific Islands' regional community and Melanesia, which includes New Guinea, Solomon Islands, Vanuatu, Fiji and New Caledonia (Blades, 2014). Despite wide diversity, Melanesians share a cultural bond. In addition to similar foods, cultivation techniques, economy and religion, Melanesia shares a tribal plan that consists of residential groupings with several small villages or local clusters (Blades, 2014). Even within West Papua there are more than 200 local tribes with their own unique languages that vary considerably across regions (Haryanto et al., 2017; King, 2004). Still there are some commonalities among them. The consumption of traditional foods such as sago and kumara (sweet potatoes) is an example of a shared tradition severely impacted by massive deforestation, which has been discussed to some degree in the literature (Blades, 2014; Kanem and Norris, 2016; Stott 2011). One of the lesser known, yet vital Papuan traditions, is the use of the multifunction tool—or net like bag—called noken.

Very little research exists on the noken in West Papua and most of it is found in Indonesian publications. Ulumuddin's (2013) discussion of the noken is one of the most recent accounts that provide general information regarding its cultural significance and its various uses in West Papua. Papuan women make noken by knitting twine/yarn produced from different kinds of tree bark — mainly from the Gnetum Gnemon tree-and the skin of wild orchids (Dekme, 2015). In some areas of West Papua, noken are used as a bag, as female clothing, and as head coverings (Ulumuddin, 2013). Each region has its specific type and function for noken. For instance, the Dani tribe call noken, Jum, Ese for the Asmat tribe, and Inoken for the Biak tribe (Ulumuddin, 2013). In addition to the variations in names, each region uses different materials to produce them. In Asmat, for example, noken is made from tree bark and leaves, and is always decorated with a variety of seeds and bird feathers. Tribes located in the highlands of West Papua, make noken also from tree bark and wild orchids, but they are less decorative. Apart from their practical functions, noken are almost always used in every traditional ceremony, including engagements, marriages, births, chief inaugurations, and heritage ceremonies (Ulumuddin, 2013).

Noken represent the prosperity of Papuans and are a symbol of their intimate relationship to nature (Marjanto, 2013). Materials used to make these bags are freely taken from the forest without any contamination. Papuans believe that damaged noken can easily return to the land. The noken has a longstanding history in Papuan culture. However, since the implementation of economic development projects, Papuans are finding natural materials, once easily accessible from the forest, more difficult to obtain (CIFOR, 2014; Hadiprayitno, 2015). There has not been an empirical examination of the noken in West Papua that centers the voices of indigenous women. This work addresses this gap by examining the relationship between traditional practices and Papuan cultural identity. It is the purpose of this study to contribute to the scholarship on Papuan women by enhancing our understanding of Papuan women's attitudes toward the noken. Drawing on the voices of Papuan women from the Merauke Regency located in the south of West Papua, this study addresses two questions: How does the noken resonate with Papuan women/community; and have perceptions of noken and its availability changed?

This qualitative case study employs a Women, Culture and Development (WCD) framework to understand the role of the noken in Papuan culture. Such an understanding, especially from the perspective of Papuan women, is necessary to bring awareness in order to develop effective strategies and interventions that draw on the knowledge and creativity of Papuans. Given the centrality of culture in a WCD approach, emphasis is on the nuanced ways Papuan women exercise their agency or the specific ways they exert power and influence within their surroundings. This paper proceeds with a brief discussion of the relationship between economic development programs and land rights in the Merauke Regency. More importantly, this discussion elucidates the relationship between the loss of native lands and cultural practices. The discussion then shifts to an analysis of interviews with four Papuan women and concludes with a discussion of the findings.

\section{DEFORESTATION AND LOSS OF NATIVE LANDS}

\section{The Merauke Integrated Food and Energy Estate}

The Merauke Regency is one of the regencies located in the southern part of the Papua province in Indonesia. It has an area of 46,791,63 $\mathrm{km}^{2}$ and is bordered to the east by Papua New Guinea (Merauke Statistical Data, 2014). The population of Merauke is nearly 250,000 - 73,000 of whom are Indigenous to the land (Indonesian Population Census, 2010). The Merauke Integrated Food and Energy Estate, known as the MIFEE project was implemented by the Indonesian government in 2010 (Hadiprayitno, 2015). The local government of the Merauke Regency in collaboration with the state government set up the MIFEE project to overcome the food and energy crisis in Indonesia. This program allocated over 970,000 hectares for commercial farming such as sugar cane, palm oil, tapioca, corn, and industrial forests (Ginting and Pye, 2013; Hadiprayitno, 2015). When the Indigenous community handed over their land as part of participation in the economic development, they were unaware of the serious 
implications for their daily lives. As stated by Borras et al. (2011), Merauke is seen by powerful transnational and national economic actors ranging from corporations to national governments as 'empty land' - a site for fuel and food production activities. The construction of public facilities and infrastructure in the rural areas of Merauke, such as housing, schools, bridges, and roads were purportedly implemented to benefit the local community. Such developments appeared to be genuine efforts from the government and companies to increase the community's wealth and well-being, but were in fact only a strategy to facilitate the implementation of the estate business. Without bridges and roads, trucks and excavators could not gain access into the forest or villages. Moreover, the natural forest products could not be loaded and transported into the city for further processing if the proper infrastructure was not in place.

Selvadurai et al. (2013) explored a similar situation experienced by the Penan natives in Serawak, Malaysia. A palm oil plantation company developed public infrastructures such as bridges, schools and community housing to supposedly improve the living standards of the local indigenous community. By the time the Penan realized their way of life was changing in ways that they could no longer sustain themselves, the company had demolished their forests and converted the land into industrial areas (Selvadurai et al., 2013). The Penan tribe, which had once been nurtured by nature and did not rely on money before modernization, found that the new market economy did not accommodate their traditional knowledge.

Like the Penan tribe, many Papuans rely heavily on the forest for subsistence. Having lived for generations from the land like the Penan, Papuans have also experienced similar challenges that have hindered their way of life (King, 2004; Lawson, 2016). Since the noken is traditionally made from raw materials found in the forest (Dekme, 2015; Ulumuddin, 2013), diminishing native forests possibly impede the Papuans' ability to produce this traditional bag and inhibit other longstanding cultural practices.

\section{Noken, Papuan Culture and Women}

As stated above, noken are used routinely across all Papuan tribes and are made to be both functional and durable (Dekme, 2015). For example, large noken are often used to carry a variety of local products such as vegetables, taro, cassava, kumara, sago, fruits or fire wood (Dekme, 2015; Marjanto, 2013). Smaller noken are used to carry traditional cigarettes, betel nuts, books and the holy bible. Special noken are made to carry babies and pigs (Dekme, 2015). Some tribes consider pigs as an integral part of their life because of their traditional values. Pigs are often used in some cultural rituals such as funerals, engagements, marriages, births, etc. In Tolikara, for example, in the highlands of West Papua, pigs play very important roles in cultural life extending back several generations (Dekme, 2015). Among these tribes, both pigs and babies are valuable and treated equally. Thus, it is common for many tribes to place pigs and babies into the same noken.

Noken also represent the female uterus and fertility (Marjanto, 2013). The elastic nature of the bag looks very small before it is filled, just the same as a female uterus during the various stages of pregnancy (Haryanto et al., 2017). Often made by mature and/or elderly women and in groups, the process of making noken provides a sense of togetherness among the women, as the women prefer to do the knitting in groups instead of working individually. For this reason, if they work together, they can motivate each other to finish the knitting while engaging in discussion (Ulumuddin, 2013). Mature Papuan women are often measured by their ability to knit noken (Marjanto, 2013; Ulumuddin, 2013). Among some tribes located in the highlands of West Papua, possessing the skills to make noken is required for marriage (Marjanto, 2013). Often a woman who is not skilled in the art will not be approached by males, or may not be allowed to marry (Marjanto, 2013). Emphasis on the essential role of the noken in Papuan culture illustrates how it is intricately woven into all facets of their lives. Understanding this complex entanglement requires a framework that accommodates the cultural reproduction aspect of Papuan identity and development.

\section{Analytical framework: Women Culture \& Development (WCD)}

The first articulations of the Women, Culture and Development (WCD) framework emerged at the end of the twentieth century. Chua, Bhavnani, and Foran's (2000) seminal article Women, culture, development: A new paradigm for development studies? addresses the limited attention paid to culture in development scholarship. In this work the authors provide a broad sketch of the specific ways the "Third World Development Project", since the 1950s, failed to achieve its primary goal of poverty amelioration. This failure is largely attributed to the overly economistic assumptions on the part of development theories and policies which rendered the complexities of Third World lived experiences, particularly women, invisible (Bhavnani, Foran and Kurian, 2003; Bhavnani, Foran, Kurian and Munshi, 2009/2016; Chua, Bhavnani and Foran, 2000). Asante (2009) argues that this immense failure is intrinsic to the design of the Third World Development Project. Because the Third World is assumed to be economically impoverished, the dependency of Third World countries is maintained by richer nations through development strategies (Chua, Bhavnani and Foran, 2000). As an appendage of Modernity, which is laden with values of EuroAmerican culture as culturally dominant and naturally conquering (Asante, 2009), modernization is assumed to be 
the desired goal (Chua, Bhavnani and Foran, 2000). From this basis, "development", by definition, "insidiously works to remove a people from its own contextual terms" (Chua, Bhavnani and Foran, 2000, p. 67).

Another important component linked to the failures of the Third World Development Projects is the way women are viewed (Bhavnani and Bywater, 2009). Viewed as either wives, mothers or as laborers, women's productive contributions beyond these roles were largely neglected from integration in development approaches. For this reason, Bhavnani and Bywater (2009) argue that while development policies, projects and theories do not necessarily make women entirely invisible, "the ways women are visible within development do not shed light on their lives in all of its wonderful complexity" (p. 62). The elements that configure this complexity are: production and reproduction, lived experiences, and cultures and agency (Bhavnani and Bywater, 2009). Agency, in this sense, refers to conditions of individualization and self-affirmation integral to women's efforts to exert power and influence within a particular social context (Bakan, 1966).

From this basis, WCD draws from three modes of inquiry: (1) feminist studies, (2) cultural studies, and (3) Third World/ development studies (Chua, Bhavnani and Foran, 2000). Central to the WCD framework is the assertion that women's lives, identities, practices and representation, form a rich tangle of production and reproduction that cannot be untangled. The WCD proposes a more complex view on the ingredients in this tangle (Bhavnani, Foran and Kurian, 2003; Chua, Bhavnani and Foran, 2000). WCD includes three main tenets:

(1) Highlights culture as lived experiences, production and reproduction (e.g. social reproduction) (Bhavnani, Foran and Kurian, 2003);

(2) Brings women's agency to the foreground within the cultural, social, political and economic domains as a means for understanding how inequalities are challenged and reproduced (Bhavnani, Foran and Kurian, 2003; Nandedkar, 2017); and

(3) Considers the economic but does not place the economic above other aspects of people's everyday lives. (Bhavnani and Bywater, 2009).

Culture, being an important element of WCD, is defined as lived experiences that are inherent in all relationships (Bhavnani, Foran and Kurian, 2003). Culture offers non-economistic and non-materialistic ways of acknowledging the multiple complexities in women's lives. It also includes the way knowledge emerges from the way people live their lives and is shifting constantly (Chua, Bhavnani and Foran, 2000). As discussed earlier, the devastating destruction of native lands through economic development projects placed a strain on Indigenous people who have long relied heavily on the forest for many purposes. Thus, it is of critical importance to understand how development projects have influenced the lived realities of Papuan culture. Given how women, noken and the forest are all inextricably linked, the WCD framework is ideal for gaining insight into these complex connections.

\section{METHODS}

This study draws from a WCD framework and thus centers the experiences of Papuan women. Special attention is devoted to an examination of their agency, specifically exploring how Papuan women exercise power in their circumstance. Thus, Indigenous women respondents are situated as epistemic agents, uniquely imbued with specialized knowledge of their own realities. Their identity as the original inhabitants of the land comes with lived experiences and an expertise to delineate contemporary issues. As credible experts of their own lived experiences, the voices of Papuan women are prioritized over research about them produced by other groups.

The principal investigator (PI) is a native of West Papua from the Merauke Regency. Her understanding of the culture as an insider/outsider was advantageous to this study because familiarity facilitated trust. A sensitivity to the women and culture, as well as an understanding of multiple languages and local dialects benefitted this study as interviews were conducted in three different languages. Most interviews were in Bahasa Indonesia or translated into Bahasa prior to English translation. Each interview took a significant amount of time. Also, the PI was able to engage in various tasks while conversing with the women. Given the political climate, the ability to blend in and gain trust was paramount.

\section{Respondents}

Data for this study are taken from a larger case study evaluation of market women in the Merauke Regency. All except one respondent, a university student, are merchant women who make their living primarily from the market. Given the potential for putting women in danger, participants were not randomly selected. The market coordinator for Indigenous women traders was consulted and thus identified suitable candidates for in-depth interviewswomen with at least five years of experience of selling in the market. Of the eight participants from the larger study, only four were Indigenous women and could speak to the history and the meaning of noken in the Papuan community. Participants were provided a recording of consent as well as information about the study translated in 
Table 1. Coding Schedule

\begin{tabular}{ll}
\hline Themes & Codes \\
\hline Access to raw materials/Deforestation & $\begin{array}{l}\text { Depleting natural supply/deforestation; Gnetum Gnemon tree; distance; } \\
\text { transportation and time }\end{array}$ \\
\hline Noken/Men & $\begin{array}{l}\text { Essential tool (fishing, gardening); ceremonial uses; clothing; expensive; rare; } \\
\text { souvenirs; scarce; changing meaning }\end{array}$ \\
\hline Women and traditional uses of noken & $\begin{array}{l}\text { Conduits of knowledges (processing tree bark, knitting); ceremonial uses; cultural } \\
\text { transmission; marginalized }\end{array}$ \\
\hline Changing perceptions of noken & $\begin{array}{l}\text { Youth; stereotypes/ primitive; unfashionable/unappealing; boarding schools (loss of } \\
\text { interest and inability to knit) }\end{array}$ \\
\hline Indonesian influence & $\begin{array}{l}\text { Synthetic fabrics/material; western/fashionable bags; access to noken; and } \\
\text { inappropriate appropriation }\end{array}$ \\
\hline
\end{tabular}

Bahasa, Indonesian and English. Given the principal investigator's status as an insider from the region, some consent was given verbally and recorded in native dialects.

\section{Interview Protocol}

Four participants were interviewed face-to-face. However, some participants felt uncomfortable with engaging at the markets, or expressed an uneasiness, because of the need to sell goods. Two interviews took place offsite. Interviews lasted between 50 minutes and roughly 1 hour and 45 minutes. Due to the women's workloads and daily chores, all but one of the four participants were interviewed while doing tasks in which the PI also participated. While the interview covered a range of topics related to Papuan merchants and negotiating market space, the questions specific to this study included: How does the noken resonate with Papuans and have perceptions of the noken and its availability changed? These questions serve to respond to the project's hypothesis: The combination of economic development programs and expanding non-Papuan influence have disrupted access to cultural products, such as the noken, which in turn influence cultural practices and ability to transmit culture.

\section{Analysis and Findings}

As stated earlier, scholarship regarding Indigenous populations in West Papua is sparse in general. Hardly any research exists regarding the noken, therefore, an inductive analysis was deemed the most appropriate approach for analysing raw data. Data were then analyzed using an open coding procedure. Each interview was coded lineby-line to establish initial themes (Strauss and Corbin 1998). Five major themes emerged (see Table 1).

\section{Access to Raw Material and Labor Process}

Accessing and processing raw material used to make noken emerged as a major theme. Each participant began their accounts with knowledge of the Gnetum Gnemon tree, beginning with its location to how it is processed into yarn. This process was described as a labor-intensive tradition undertaken by Papuan women. Yet, the participants all spoke fondly of this procedure. Possessing this knowledge was considered of great value and a source of pride. This pride was also extended to the noken, especially in describing the noken as an essential toolused in almost every aspect of Papuan life. Participants' recollections of noken began as early as childhood memories of being carried in noken slung over their mothers' backs or describing how women hang noken with their babies inside from tree branches to keep the child out of reach of wild animals while they work from morning to late afternoon. Two participants detailed this process and often referred to noken by their tribal term-men. Noken is made from tree bark of the Gnetum Gnemon tree which grows wild in the forest and mountainous area of Boven Digoel Regency. The leaves from Gnetum Gnemon are usually consumed as vegetables, or taken to be sold at the market, while the bark is taken to be dried for further processing. The dried tree bark is what is twisted into very thin yarn, and woven into noken. The women then take the leaves of the Gnetum Gnemon tree to sell at the market. Most women tend to do this work in their free time. Due to the lack of access to the forest for basic needs, many of the women's priorities have shifted to having to depend more on selling local goods at the market.

\section{Synthetic Materials}

The prevalence of synthetic materials as a cheaper alternative to raw material emerged often and always in a disapproving manner or tone. Dometria and Theresia both expressed concern over women having to rely more heavily on synthetic materials because raw materials were too costly or too time consuming to obtain. Deforestation through economic development programs had placed a strain on women's ability to access raw materials, therefore they turned to synthetic materials, which were more readily available through Indonesian merchants. Because women must travel long distances to the forest, they lacked the time and transportation to travel to places where the Gnetum Gnemon tree still grew widely. Synthetic materials were described as unnatural and lacking durability, but were cheaper substitutes. 


\section{Noken: Essential Tool, Cultural Identity, and Women's Work}

Two participants discussed specifically the noken in relation to their tribe, the Muyu. The Muyu tribe inhabit an area near the country's border with Papua New Guinea. Noken from this region are called men. Two participants, Dometria and Theresia, from this region both expressed how the men is an essential tool used in almost every aspect of the Muyu's day-to-day tasks. Fishing (from rivers and swamps) and hunting are the main livelihoods for the Muyu. Theresia lives in the suburb of Merauke city and stated that noken (or men) represent the cultural identity of the Muyu tribe. As a little girl, she learned how to knit noken from her mother. She emphasized that noken are always identified with Muyu women because Muyu women have a huge responsibility to provide food for their families. Both Dometria and Theresia stated that the Muyu use traditional tools to conduct their daily tasks and men were one of the most important tools.

\section{Women: Laborers, Conduits, and Guardians}

Multiple references to women and noken were identified across all the participants' transcripts with women as: (1) possessors of this knowledge, (2) conduits of this knowledge, and (3) primary users of this knowledge. Theresia, however, referenced a special connection between noken/men and Muyu women:

The men (noken) is connected to women because of the domestic roles as family food suppliers. The main function of men is to carry our local products from garden-vegetables, fruits, tubers, and traditional medicines. We [Muyu women] use men to carry our babies when we garden.

As stated earlier, participants often spoke of the work required to make noken, especially from raw materials, as time consuming. However, the work was never described as burdensome. Rather, this knowledge was embraced as a special art form uniquely Papuan. A participant from the Muyu tribe spoke to the unique way Muyu women make noken stating that the Muyu women's way of making noken could not be replicated by Indonesian women or Papuan women from other tribes. Each participant spoke of the noken and the ability to make noken with immense pride.

\section{Labor and Cost}

Noken are becoming harder to acquire and thus more expensive. One participant articulated that although noken were a physical representation of Papuan culture, noken were becoming out of reach for many Papuans due to how expensive they had become:

In Merauke Regency, in the South of West Papua, the price of noken is very expensive because of the difficulty in finding raw materials. Raw materials are usually imported from Boven Digoel regencies, which is $450 \mathrm{~km}$ away from Merauke city by car. The price of one large-size noken is 300,000 rupiah (NZD \$32), and the small size is around 150,000-200.000 rupiah (NZD \$17-\$22). Most Papuans are not really interested to buy noken because of the price that is quite expensive. They tend to buy modern bags which are cheaper and more attractive.

Larger size men, according to Theresia, are used in several cultural ceremonies. For instance, engagement ceremonies require that a noken is used to collect all of the traditional goods requested by the woman's family. Money and tobacco/traditional cigarettes are usually put in smaller sized noken. Neka, a younger Papuan woman, wore a noken from her head with one small stone placed inside. Wearing the noken in this way, she explained, symbolized her engagement to be married and ensured that she would not be approached by potential suitors.

\section{Inter-generational Changes}

Youth, or the younger generation, emerged as a key theme. A strong Indonesian influence at the market has provided the younger generation more access to fashionable or modern apparel. Preferring modern bags to traditional bags, the youth, according to the participants, perceived traditional bags, like the noken, as "primitive." Two of the participants with daughters noted a shift in cultural values towards a growing preference for modern bags/purses. A preference toward more fashionable bags was an issue raised in association with a larger concern of a loss of interest in knitting among the Muyu's younger generation. Many of the young girls from this tribe were losing the ability to knit noken. One mother attributed the loss of this cultural skill to the establishment of boarding schools, which were located long distances from villages. Therefore, young girls must leave their villages and live at the schools. Cultural practices like noken knitting are not included in the school curriculum.

\section{The Transmission of Culture}

While education is encouraged for their daughters and the girls in the community, the participants feared that the younger generation were losing their traditional ways. Typically, Papuan women, in groups or one-on-one, 
teach their daughters to knit because it is highly regarded as a form of education in terms of equipping girls with essential skills for the future. One participant said, "Woman's ability to knit noken makes her more desirable for her husband and his family." Knitting was not described as an oppressive task. Another participant recalled her struggle to spark a passion for knitting in her daughter because she felt she had to compete with the influences of city life and school activities (e.g. television, music, friends and school activities). Another participant, who was a university student, recalled being encouraged to knit noken, but lost interest soon after she moved to Marauke to study. Each time she returned to her village, she was reminded of this important skill and felt disappointed because of her inability to contribute to her tribe in this way.

\section{Non-Papuan Influences}

An acute awareness of a non-Papuan presence and influences permeated the participants' discussions. NonPapuan influences were often associated with stereotypes of primitive, Indonesian merchants and products, and the appropriation of Papuan goods, tools, and foods. One participant recalled an advertisement of Indonesian models wearing a noken inappropriately. Finding it disrespectful, she said the way it was worn changed the meaning of the noken altogether and was evidence that non-Papuans do not know Papuan culture, or respect it.

Seeing noken sold as souvenirs evoked feelings of concern. The same participant mentioned that she found it strange seeing noken sold as souvenirs especially when they are becoming too expensive for Papuans to purchase. She expressed that while noken belong to Papuans, they were losing them to outsiders. Moreover, Papuans are struggling to survive by producing their traditional bags. With access to the forest they could make enough for themselves and to sell. Now many Papuans are having to sell noken along the roadside, at markets and at airports.

Having relied for so long on the forest for basic foods and materials, some Indigenous women (e.g. Wamena) knit noken aimed at tourists in order to earn money. Most of the participants stated that the philosophy of noken is lost as these types of exchanges become the norm. The noken is increasingly becoming commodified. The women maintained that preserving the philosophy of the noken was equally as important as preserving the art form and its accessibility for Papuans.

\section{DISCUSSION}

The findings revealed that the noken is regarded by Papuans as a material representation of Papuan identity and culture. Participants only discussed economics when expressing dismay at how expensive it had become to travel to retrieve raw materials to make noken, which in turn led to the expensive costs of the traditional bag. Rather, emphasis was placed on the weakening significance of noken in Papuan culture brought on by a multiexploitative process: marginalization, commercialization, and appropriation. Regarded as a longstanding art form that cannot be disentangled from Papuan identity, the noken was described as a tool that connected the people to the land and to each other. Thus, the skill of noken making was described as a specialized knowledge, a culture, a symbol, an art form, and an essential tool rooted in Papuan identity. This understanding is consistent with the WCD framework thesis that espouses culture as an entanglement that is essential to women's lived experiences, and disconnected from economic gains. In addition to this understanding, the findings offer new insights into the use of noken as an instrument of resistance in response to marginalization.

For example, diminishing noken supplies were at the forefront of the participants' articulations of concerns, which they linked to larger structural factors (e.g. deforestation and non-Papuan influences). The women described such losses as a threat to Papuan identity that intricately related to the ability of Papuans to maintain their way of living. Rebecca Tsosie (2017), discusses a similar trauma experienced by Native Alaskan communities (p. 361):

Following the 1989 Exxon Valdez oil spill, several Native Alaskan communities sued Exxon for the destruction of their traditional subsistence way of life caused by the massive oil spill. The federal court described culture as an 'internal' state of mind, which could not be destroyed unless a person lost the 'the will' to pursue a given way of life. The harm to the Indigenous group was multiplied, disrupting longstanding practices, customs and ceremonies that integrated the people with their environment. The people could not 'live' their culture or transmit it to their children because of the destruction of the environment and associated wildlife resources.

This example illustrates the power dynamics regarding who has the power to define culture. In this case, the United States federal court ruling defined culture as something solely from within the people and separate from the environmental resources that had sustained them for generations. Moreover, Native Alaskans were not extended the right to speak as agents of knowledge, but as people passively "having" culture. In the same way, Papuan women raise similar concerns about the future availability of the noken for customs, practices, and ceremonies. More importantly, participants discussed the essential role of Papuan women as conduits of this 
knowledge. But like the example, it is not knowledge that is recognized as deserving protection (Tecu, 2017). Therefore, Papuans experience a certain harm that results from their diminishing ability to live out their culture.

Within the context of coloniality, stereotypes have been used to create and reinforce racial hierarchies, especially as they relate to the social construction of Indigenous peoples as "others" (Cooper, 2012; Norris, 2017; Smith, 2012; Tsosie, 2017). Papuan women discussed that their goods compared to those of Indonesian merchants are deemed as "traditional" as opposed to the more modern or Western items sold by Indonesian merchants. The Indonesians brought with them a market economy that has replaced the barter economy that once organically unified Papuan culture. Through this process, a power-elite emerged, whether by default or design, a power imbalance in which Papuans have found themselves at the bottom.

Often deployed to reinforce racial hierarchies, negative stereotypes are intricately linked to the control of knowledge and are a form of racism on which coloniality hinges (Cooper 2012). As Mignolo (2000) and Maldonado-Torres (2004) argue, "through the coloniality of power matrix, the development of a racial classificatory system and the control of knowledge, is pivotal to coloniality" (as cited in Cooper 2012, p. 69). This study reveals that Papuan women do possess a specialized unwritten knowledge that has been relegated to the margins and excluded within broader mainstream society. Cooper (2012) explains this process as an aspect of coloniality wherein Indigenous people are considered to have culture as opposed to knowledge.

Papuans, especially the women, are unable to compete with foreign labor (Forest Peoples Programme, 2011). Modernity, as experienced by Papuans, has disrupted and destroyed longstanding cultural practices that have sustained Papuans and forced them into a situation of dependency on a foreign way of life. Furthermore, as economic development projects have marginalized and alienated Papuans through the lack of employment opportunities (Stott, 2011), many Papuans are left without proper knowledge and skills in modern agriculture. As a result, Papuans are having to rely more on the market. Adapting to so-called advancements requires new skills and access to decision-making processes that will facilitate access to the necessary knowledge. For the most part, Papuans have been locked out of this process and thus inhibited from achieving economic mobility (Stott, 2011). Furthermore, massive deforestation has made it impossible for many Papuans to return to their traditional ways of sustaining themselves.

The stigma associated with the noken is one example of the marginalization Papuans experience. Noken's stigmatization as a "traditional" artefact is reinforced through the bags becoming tokenized as a souvenir and disrespectfully appropriated by non-Papuans as a "primitive" type of attire. While the noken has been officially designated by the United Nations Educational, Scientific and Cultural Organization (UNESCO) as a world cultural heritage (Dekme 2015), Papuan women feel powerless to contest various types of mistreatments. Smith (2012, p. 61) uses the concept of "positional superiority" to describe how the imposition of knowledge and culture were as much a part of imperialism as the extraction of raw materials and the exertion of military strength. This concept also provides insight as to why the inappropriate appropriation of noken have not been charged as an offense against Papuan culture despite Papuan claims of mistreatment. This illuminates Papuans' strategic position in terms of their distance from social and political power to protect and validate their ways and knowledge.

Competing influences from non-Papuan culture/groups have come to dominate Papuan social settings. Massive deforestation has given rise to distinct forms of marginalization that have constrained Papuan cultural practices. Thus, Papuan knowledge has come to hold new meaning in response to a shifting social context. This paper argues that Papuan knowledge, specifically the noken, is in many ways of increased value. For example, noken knitting was once viewed as a common practice embedded in Papuan culture. Now that this cultural art form is threatened, it has taken on new meanings. Papuans' use of this knowledge has extended beyond the practice of a cultural art form to the enactment of a resistance knowledge project. Papuan women exercise their agency by resisting negative labels that seek to exclude their cultural practices as knowledge and by embracing their role as conduits of Papuan knowledge.

\section{CONCLUSION}

This study addresses the overall silence around the contemporary experiences of Papuan women. It provides insight into the realities of their marginalization through an examination of the noken. Using a Women, Culture and Development framework, this study, reveals that the noken resonates in the consciousness of Papuan women as a longstanding art form integral to Papuan identity. A combination of factors including limited access to raw materials, harmful appropriations and influx of goods sold by non-Papuans have negatively influenced access to, and the perceptions of, the noken. This study argues that this type of damage is rooted within the broader matrix of coloniality. From this perspective, important questions around the control of knowledge, and what constitutes legitimate knowledge deserve further investigation. If interventions are to be established to expose and rectify harmful practices impeding Papuans from living and reproducing their culture, Papuan voices must be elevated to a level of salience wherein their knowledge is accorded respect and legitimacy. It is only from this basis that 
effective strategies can be formulated to protect Papuan knowledge, which will in turn safeguard Papuan identity. The intricate ways Papuan customs, environment, and goods are intertwined are essential to the production and reproduction of Papuan identity.

\section{REFERENCES}

Asante, M. (2009). Resisting westernity and refusing development, in K. Bhavnani, J. Foran, P. Kurian, and D. Munshi (eds), On the Edges of Development: Cultural Interventions (pp. 67-76). New York City, NY: Routledge.

Bakan, D. (1966). The Duality of Human Existence: An Essay on Psychology and Religion. Chicago, IL: Rand McNally.

Banivanua-Mar, T. (2008). "A thousand miles of cannibal lands": Imagining away genocide in the re-colonization of West Papua. Journal of Genocide Research, 10(4), 583-602. https://doi.orig/10.1080/14623520802447743

Berkes, F., Colding, J. and Folke, C. (2000). Rediscovery of traditional ecological knowledge as adaptive management. Ecological Applications, 10(5), 1251-1262. https://doi.orig/10.1890/1051-0761

Bhavnani, K. and Bywater, K. (2009). Dancing on the edge: Women, culture and a passion for change, in K. Bhavnani, J. Foran, P. Kurian, and D. Munshi (eds), On the Edges of Development: Cultural Interventions (pp. 52-66). New York City, NY: Routledge.

Bhavanani, K., Foran, J. and Kurian, P. (2003). An introduction to women, culture and development, in K. Bhavnani, J. Foran and P. Kurian (eds), Feminist Futures: Re-imagining Women, Culture and Development (pp. 1-12). London, UK, New York, NY: Zed Books Ltd.

Blades, J. (2014). Melanesia's test: The political quandary of West Papua. Pacific Journalism Review, 20(2), 23-39. https://doi.org/10.24135/pjr.v20i2.164

Chua, P., Bhavnani, K. and Foran, J. (2000). Women, culture, development: a new paradigm for development studies? Ethnic and Racial Studies, 23(5), 820-841. https://doi.org/10.1080/01419870050110913

CIFOR, (2014). Oil palm estate development and its impact on forests and local communities in West Papua. Available at: https://www.cifor.org/publications/pdf_files/WPapers/WP156Komarudin.pdf (Accessed 19 March, 2018)

Cooper, G. (2012). Kaupapa Maori research: Epistemic wilderness as freedom? New Zealand of Educational Studies, 47(2), 64-73.

Dekme, D. (2015). Noken craftsmen at Amungme peoples village in Limau Asri Village Iwaka District Minmika Regency Papua Province. Journal of Holistic \& Bullet, 16, 1-12.

Ginting, L. and Pye, O. (2013). Resisting agribusiness development: The Merauke Integrated Food and Energy Estate in West Papua, Indonesia. ASEAS-Austrian Journal of South-East Asian Studies, 6(1), 160-182.

Hadiprayitno, I. I. (2015). Behind transformation: The right to food, agricultural modernisation and indigenous people in Papua, Indonesia. Human Rights Review, 16, 123-141. https://doi.org/10.1007/s12142-015-0353-7

Haryanto, T. N. and Subanji S. R. (2017). Ethnomathematics in Arfak (West Papua-Indonesia): Numeracy of Arfak. International Journal of Scientific \& Technology Research, 6(9), 325-327.

Ikoja-Odongo, R. (2009). A framework for developing a knowledge base for indigenous ecological knowledge in Uganda. ES ARBICA Journal, 28, 207-221. https://doi.org/10.4314/esarjo.v28i1.44404

Kanem, V. T. and Norris, A. N. (2016). Indigenous women, traditional goods, and identity: Voices of Papuan women from the Merauke Regency of Papua province. Women Talking Politics, 1, 7-9.

King, P. (2004). West Papua \& Indonesia since Subarto: Independence, autonomy or chaos? Sydney, AU: University of New South Wales Press Ltd.

Lawson, S. (2016). West Papua, Indonesia and the Melanesian spearhead group: competing logics in regional and international politics. Australian Journal of International Affairs, 70(5), 506-524. https://doi.org/10.1080/10357718.2015.1119231

Maldonado-Torres, N. (2004). The topology of being and the geopolitics of knowledge: Modernity, empire and coloniality. City, 8(1), 29-56. https://doi.org/10.1080/1360481042000199787

Marjanto, D. (2013). Makna dan fungsi noken dalam kehidupan Masyarakat Papua, in H. D. Ismadi (ed). Kebudayaan Indonesia: Lestarikan Apa Yang Hendak Dilestarikan (pp. 22-34). Indonesia: Pusat Penelitian.

Mignolo, W. D. (2000). Local histories/Global designs: Coloniality, subaltern knowledges and border thinking. Princeton, NJ: Princeton University Press.

Nandedkar, L. (2017). Translating MDG 3: Gender, Empowerment and the Adolescent Girl in Maharashtra, India. Ph.D diss., University of Waikato, Waikato New Zealand.

Norris, A. N. (2017). Are we really colour-blind? The normalization of mass female incarceration. Race and Justice, 1-25. https:// doi.orig/10.1177/2153368717718028

Raschke, V. and Cheema, B. (2008). Colonisation, the new world order, and the eradication of traditional food habits in east Africa: Historical perspective on the nutrition transition. Public Health Nutrition, 11(7), 665-666. https://doi.org/10.1017/S1368980007001140 
Selvadurai, S., Er, A.C., Lyndon, N., Sum, S., Saad, S., Manal, A. A. and Ramli, Z. (2013). Penan natives' discourse for and against development. Asian Social Science, 9(8), 72-78. https:// doi.org/10.5539/ass.v9n8p72

Smith, L. (2012). Decolonizing methodologies: Research and indigenous peoples (Second Edition). Dunedin, NZ: University of Otago Press.

Strauss, A. L. and Corbin, J. (1998). Basics of Qualitative Research: Techniques and Procedures for Developing Grounded Theory. Thousand Oaks, CA: Sage publications.

Stott, D. (2011). Indonesian colonisation, resource plunder and West Papuan grievances. Asia-Pacific Journal, 9(12), $1-33$.

Tecun, A. (2017). Tongan kava: Performance, adaptation, and identity in diaspora. Performance of the Real E-journal, $1(1), 52-64$.

The Forest Peoples Program (2013). A sweetness like unto death: Voices of the indigenous Malind of Merauke. Available at https://www.forestpeoples.org/en/topics/other-private-sector/publication/2013/sweetnessunto-death-voices-indigenous-malind-merauke-p (Accessed 19 March, 2018).

The World Bank, Indonesia Population Census 2010, Central Bureau of Statistics, (Minneapolis, MN, 27 January 2017), distributed by the University of Minnesota.

Tsosie, R. (2017). Indigenous peoples, anthropology, and the legacy of epistemic injustice. In The routledge bandbook of epistemic injustice, edited by Ian James Kidd, José Medina, and Gaile Pohlhaus, Jr. New York City, NY: Routledge.

Ulumuddin, I. (2013). Uniquely noken, cultural heritage tak benda from Papua, in H. D. Ismadi (ed). Kebudayaan Indonesia: Lestarikan Apa Yang Hendak Dilestarikan (pp. 9-21). Indonesia: Pusat Penelitian.

Wardis, G. (2014). Socio-economic factors that have influenced the decline of sago consumption in small islands: A case in rural Maluku, Indonesia. South Pacific Studies, 34(2), 99-116. 